\title{
Pliocene ostracods (Crustacea) from the Togakushi area, central Japan; palaeobiogeography of trans-Arctic taxa and Japan Sea endemic species
}

\author{
HIROKAZU OZAWA ${ }^{1}$, HIDEAKI NAGAMORI ${ }^{2} \&$ TOMOTAKA TANABE $^{3}$ \\ ${ }^{1}$ Department of Geology, National Museum of Nature and Science, Tokyo, 3-23-1 Hyakunin-cho, Shinjuku-ku, Tokyo 169-0073, Japan \\ (e-mail: ozawahi@kahaku.go.jp) \\ ${ }^{2}$ Institute of Geology and Geoinformation, Geological Survey of Japan, AIST, 1-1-1 Higashi, Tsukuba 305-8567, Japan \\ ${ }^{3}$ Togakushi Museum of Natural History, 3400 Tochihara, Togakushi, Nagano 381-4104, Japan
}

\begin{abstract}
Pliocene strata (4-3 Ma) in the Togakushi area, central Japan, yield significant ostracods, which allow investigation of the origins of high-latitude (Arctic-Atlantic) taxa and the Japan Sea endemic species, together with their post-Miocene history of extinction-speciation and migration. Three types of extinct species are found here: (1) cryophilic species in common with, or closely related to, species in Plio-Pleistocene assemblages described from the Japan Sea; (2) species closely related to, or comparable with, species that characterize Miocene Japan; and (3) species endemic to the Pliocene Japan Sea. Type (1) contains species closely related to high-latitude species known from the Arctic and northern Atlantic Oceans. Their presence suggests migration from the northwestern Pacific to the northern Atlantic through the Arctic seas since the Late Pliocene after the opening of the Bering Strait. Both Types (2) and (3) contain genera originating in the south, which show high specific diversity in regions affected by the modern warm Kuroshio Current. Ancestral ostracods of Types (2) and (3) invaded the Japan Sea from the Pacific from the Middle Miocene, and diversified to produce closely related species in the semi land-locked Japan Sea until the Early Pliocene. Two new species Aurila togakushiensis sp. nov. and Aurila shigaramiensis sp. nov. are described. J. Micropalaeontol. 27(2): 161-175, November 2008.
\end{abstract}

KEYWORDS: Pliocene, ostracods, Togakushi, Japan, palaeobiogeography

\section{INTRODUCTION}

Key insights for modelling the potential impact of future environmental fluctuations on the world's biota are provided by examining the effects of environmental change on biodiversity from the geological past (e.g. Thomas \& Gooday, 1996; Cronin et al., 1999). Predictions of migration and extinction-speciation in response to possible future environmental fluctuations can be obtained from studies on biotic responses of past shallow-sea benthic faunas to environmental change caused by geological events in the Late Cenozoic (Cronin \& Raymo, 1997; Boomer et al., 2003; Amano, 2005; Whatley et al., 2005). Species compositions of the shallow-marine benthic fauna, particularly marginal seas surrounded by land, are influenced most strongly by both marine and continental environmental changes. Both species compositions and environments changed more rapidly in the Late Cenozoic than at any other time. For this reason, fossil analysis of the Late Cenozoic shallow-sea benthos and its relationship to oceanic environment in the marginal sea have become increasingly important.

The shallow-marine benthic faunas in the Japan Sea along the northwestern Pacific margin changed drastically during the Late Cenozoic (Chinzei, 1991; Hanagata, 2003) in response to major geological events in and around this region. Such events included the Japan Sea developing during back-arc spreading (20-15 Ma), the closure of the southern strait of the Japan Sea $(10-3 \mathrm{Ma})$ and the opening of the Bering Strait in the North Pacific (5-2 Ma) (e.g. Koizumi, 1992; Tada, 1994; Otofuji et al., 1994; Hoshi \& Takahashi, 1999; Ogasawara, 2001).

Japan Sea benthic ostracods are ideal for such studies because of their responses to environmental change and abundance in both Late Cenozoic strata and modern surface sediments (e.g. Ozawa et al., 2004a; Ozawa, 2006). The cryophilic (less than $5^{\circ} \mathrm{C}$ water temperature in winter) ostracod fauna, including closely related high-latitude (Arctic-Atlantic) species, flourished in the shallow Japan Sea in the Late Pliocene and Pleistocene (Cronin \& Ikeya, 1987) and attained their highest diversity in the Early Pleistocene, c. 1.5 Ma (Ozawa \& Kamiya, 2005a). Many of these ostracods are now extinct and only a few remnant cryophilic species are known to inhabit restricted shallow waters in, and around, the modern northern Japan Sea (Ozawa, 2003a, 2004; Ozawa et al., 2004b). The sequence of species diversity from flourishing to near extinction relates to a series of environmental fluctuations in the Pleistocene Japan Sea that are now well understood as a result of recent studies (Ozawa, 2003b, 2007; Ozawa \& Kamiya, 2005a).

To date, few attempts have been made to document the Pliocene (4-3 Ma) shallow-water ostracod assemblages of the Japan Sea. Previous studies were conducted on slightly younger ostracods from the Late Pliocene, c. 3-2 Ma (Ishizaki \& Matoba, 1985; Cronin \& Ikeya, 1987; Irizuki, 1989, 1996; Cronin et al., 1994; Ozawa, 1996; Ozawa \& Kamiya, 2001; Yamada et al., 2002, 2005; Irizuki et al., 2007) and those from the Late Miocene (8-7 Ma; Irizuki, 1994). A gap exists in the faunal record for both ostracod species composition and distribution in the Japan Sea between $7 \mathrm{Ma}$ and 3 Ma.

The 4-3 Ma Pliocene strata are restricted to the Togakushi area of central Japan and contain abundant, shallow-water, calcareous fossils (e.g. Amano \& Karasawa, 1993; Nagamori, 1998). The purpose of this study was to ascertain the Pliocene (4-3 Ma) shallow-water ostracod composition from the Togakushi area, and to discuss the origins of cryophilic species closely related to high-latitude taxa and the endemic species in the Japan Sea, together with their post-Miocene history of the extinction-speciation and migration. 


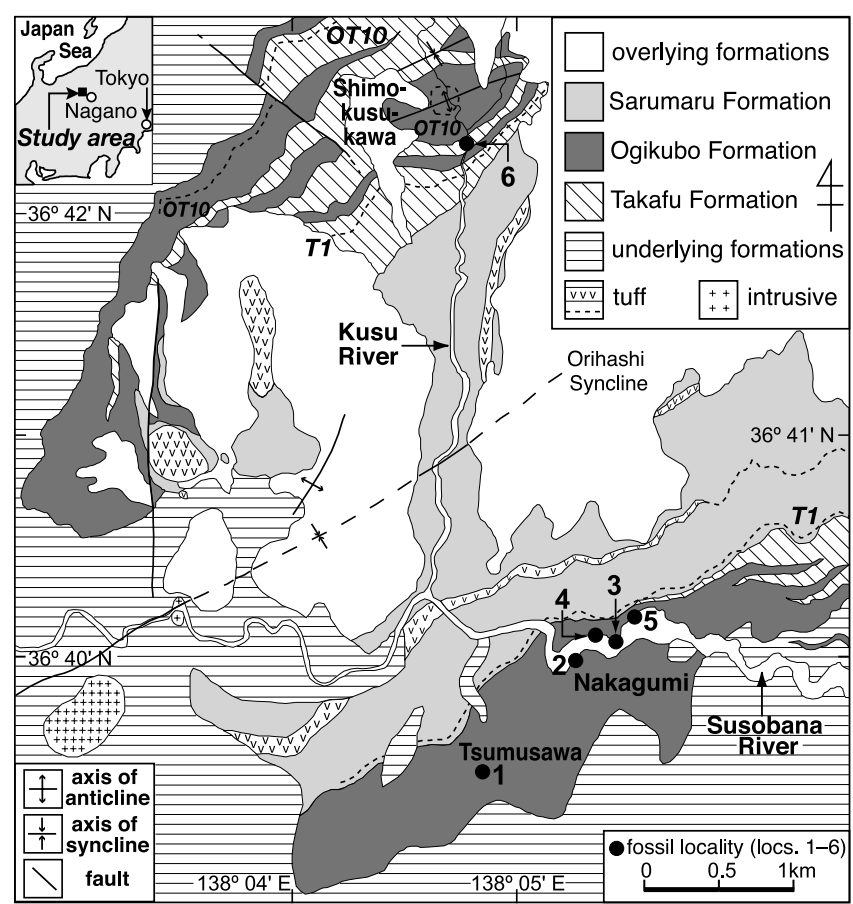

Fig. 1. Distribution of the Takafu and Ogikubo formations in the Togakushi area, showing localities for ostracod fossils, modified from Nagamori (1998) and Nagamori et al. (2003). T1 and OT10 are tuff names.

\section{GEOLOGICAL SETTING}

The Takafu and Ogikubo formations occur in the Togakushi region, approximately $10 \mathrm{~km}$ northwest of Nagano City, central Japan (Fig. 1). The stratigraphy was described in detail by Amano \& Karasawa (1993), Nagamori (1998) and Nagamori et al. (2003), demonstrating that these formations overlie the Arakurayama Formation, both conformably and unconformably, with localized intercalation in places (Fig. 2). The Takafu Formation is composed mainly of mudstone containing molluscan fossils, with fine- to coarse-grained sandstones. The Ogikubo Formation interfingers with the Takafu Formation and is composed mainly of tuffaceous, fine- to coarse-grained sandstones and conglomerates that yield abundant molluscan fossils. The Takafu and Ogikubo formations are conformably overlain by the Sarumaru Formation.

The Early to Late Pliocene planktic foraminifers Globigerina apertura and Neogloboquadrina dutertrei occur in the uppermost Ogikubo Formation, and indicate the lower part of Zone N21 of Blow (1969) dated as c. 3.0 Ma (Tsuchi \& Ibaraki, 1988; Fig. 2). Radiolarians of the Spongurus pylomaticus Zone (5.2-4.5 Ma) occur in the Arakurayama Formation, and Pliocene radiolarians of the Spongurus pylomaticus Zone-lower Cycladophora sakaii Zone (5.2-2.6 Ma) are found from the Ogikubo Formation (Motoyama \& Nagamori, 2006). These age determinations were confirmed by fission-track age of zircons from tuff layer OT10 in the lower part of the Ogikubo Formation, 3.6 $\pm 0.2 \mathrm{Ma}$ (Nagamori et al., 2003), whilst basaltic lava from the Arakurayama Formation has a $\mathrm{K}-\mathrm{Ar}$ age of $4.2 \pm 0.6 \mathrm{Ma}$ (Nagamori et al., 2003). The age of the Takafu and Ogikubo formations is considered to be c. 4-3 Ma (Fig. 2).

\section{MATERIALS AND METHODS}

Six sediment samples were collected for fossil ostracod analysis from horizons containing molluscan fossils in the Togakushi region (Figs 1 \& 2). Five were fine- to medium-grained tuffaceous sandstone from the Ogikubo Formation in the Tsumusawa and Nakagumi areas (locations 1-5) and one was from a silty, fine-grained sandstone from the Takafu Formation in the Shimo-Kusukawa area (location 6). Some 80-320 g of dried sediment samples were disaggregated using a saturated sodium sulphate solution and naphtha, washed through a $63 \mu \mathrm{m}$ (250-mesh) sieve, and then oven-dried at $80^{\circ} \mathrm{C}$. This procedure was repeated until the whole sediment sample had disintegrated. Approximately 200 ostracod specimens were picked from fractions between $0.25 \mathrm{~mm}$ and $1.0 \mathrm{~mm}$ for each sample split. This method ensured that all adults and, depending on species, A-2 or A-3 juvenile stages were obtained.

All specimens examined in this paper are deposited in the Department of Geology, National Museum of Nature and Science, Tokyo, Japan.

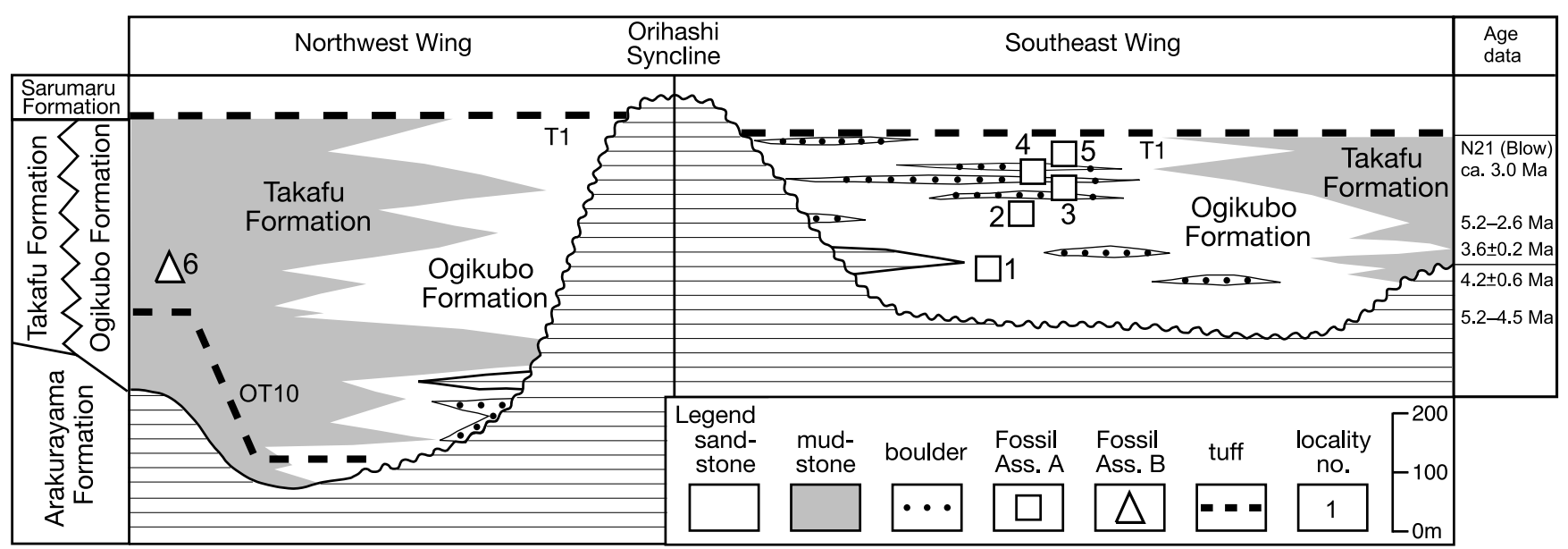

Fig. 2. Schematic geological cross-sections for the Takafu and Ogikubo formations in the Togakushi area, showing the stratigraphical distribution of ostracod fossil assemblages A and B with age data, modified from Nagamori (1998). Age data are cited from Tsuchi \& Ibaraki (1988), Nagamori et al. (2003) and Motoyama \& Nagamori (2006). 


\section{FOSSIL OSTRACOD ASSEMBLAGES}

Ninety-four ostracod species were identified in the six samples from the Togakushi area (Table 1). Approximately 40-50 species accounted for the 200 specimens from each of the Ogikubo Formation samples (locations 1-5). Plates 1 and 2 illustrate the dominant ostracod taxa from this area. Species diversity, calculated by the Shannon-Weaver function, was c. 3.0-3.5 (Table 1). The single Takafu Formation sample (location 6) yielded just four individuals of two species, despite ostracod specimens being picked from all fractions. The absolute abundance of ostracod fossils (=number of all specimens per $100 \mathrm{~g}$ sample weight) in the five Ogikubo Formation samples was c. 80-350 and considerably higher than the one Takafu Formation sample that returned a value of close to unity (Table 1).

Two fossil assemblages, $\mathrm{A}$ and $\mathrm{B}$, could be distinguished based on the dominant ostracod genera, their absolute abundance and the associated lithofacies. Assemblage A occurred in the fine- to medium-grained sandstone of the Ogikubo Formation (locations 1-5; Fig. 2) and showed much higher species number and ostracod abundance than assemblage B. Assemblage A was dominated by the shallow-sea genera Aurila, Finmarchinella, Cythere, Howeina and Urocythereis?, accompanied by Acuticythereis?, Callsitocythere, Cornucoquimba, Cytheropteron, Hemicythere, Loxoconcha, Pontocythere, Schizocythere, Semicytherura and Xestoleberis. Individual numbers of these 15 genera accounted for $c .90 \%$ of the ostracods in these five samples, with 20 species making up c. $70 \%$ of the total individuals (Table 1). Today, common species in assemblage A inhabit the algae-rich environments of rocky coasts and sandy bottoms on the upper continental shelf of the northern Japan Sea off Hokkaido Island, with water temperatures of $0-20^{\circ} \mathrm{C}$ in summer and $0-5^{\circ} \mathrm{C}$ in winter. Typical taxa include Cythere golikovi, Cytheropteron sawanense and Schizocythere kishinouyei (Ozawa et al., 1999, 2004b; Ozawa, 2003a). High species numbers and an abundance of fine- to medium-grained sand sediments characterize the upper-shelf environment of the modern Japan Sea (Ozawa, 2003a).

Assemblage B contained just two genera, Robertsonites and Macrocypris?, and occurred in the one silty, fine-grained sandstone sample from the Takafu Formation (location 6; Fig. 2). This assemblage was characterized by very low species number and specific abundance (Table 1), which, together with the species composition of Robertsonites hanaii and Macrocypris? sp., were typical of the ostracod assemblages in muddy sediments of the lower continental shelf and slope areas of the present-day Japan Sea, where the water temperature remains at $0-5{ }^{\circ} \mathrm{C}$ throughout the year (e.g. Ikeya \& Suzuki, 1992; Ozawa, 2003a; Ozawa \& Kamiya, 2005b).

Assemblage A contained many extinct species that could be grouped into three categories:

Type 1: Cryophilic (flourished during glacial periods) species that characterize Late Pliocene and Pleistocene strata along the Japan Sea coast (e.g. Tabuki, 1986; Cronin \& Ikeya, 1987; Irizuki, 1993) and their close relatives and comparable species, such as Cornucoquimba sp. 1, Hemicythere kitanipponica, Howeina sp., Kotoracythere sp., Paijenborchella tsurugasakensis, Pectocythere cf. daishakaensis, Semicytherura subundata, S. sp. 1 and $S$. sp. 2.
Type 2: Species closely related to, and comparable with, those found in Early to Middle Miocene strata along the southwestern Japan Sea coast, e.g. from the Yeonil Group (Huh \& Paik, 1992; Huh \& Whatley, 1997) and in the Sunagozaka, Omori and Fujina formations (Tanaka et al., 2002, 2004; Tanaka, 2003) (Fig. 3c). These taxa include Callistocythere $\mathrm{cf}$. kyongjuensis, C. cf. seojeongriensis, C. cf. subsetanensis and Schizocythere cf. sakanouei.

Type 3: Species that are probably endemic to this area and have no known modern or fossil records and include Aurila togakushiensis, A. shigaramiensis, Callistocythere sp. 1, C. sp. 2, C. sp. 3, C. sp. 4, Howeina? sp., Loxoconcha sp. 2, Loxoconcha? sp. 1, Loxoconcha? sp. 2, Urocythereis? sp. 1, Urocythereis? sp. 2 and Urocythereis? sp. 3. (Many of these taxa are still not formally described.)

\section{DISCUSSION}

Extinct species from the Ogikubo Formation provide major indicators of palaeobiogeographical conditions affecting the benthos and ostracod faunas of the Japan Sea and northwestern Pacific. This formation yielded significant ostracods containing three types of extinct species to investigate the origins of endemic species in the Japan Sea and high-latitude (ArcticAtlantic) species, together with their post-Miocene history of speciation-extinction and migration.

Type (1) included cryophilic ostracods in common with, or closely related to, species known from the Plio-Pleistocene (post-2 Ma) Japan Sea, such as Semicytherura species ( $S$. subundata, S. sp. 1, S. sp. 2) and Paijenborchella tsurugasakensis. They are closely related to high-latitude species from Arctic-Atlantic seas, such as Semicytherura undata and Munseyella sp. A of Brouwers (1994) (e.g. Cronin et al., 1993), and are found from Togakushi with extant species both in high latitudes and the Japan Sea, such as Acanthocythereis dunelmensis and Palmenella limicola.

According to Brouwers (1994), A. dunelmensis, Elofsonella concinna, Finmarchinella logani, Munseyella sp. A, P. limicola and Robertsonites tuberculata first appeared around 3.0-2.5 Ma in the Arctic Ocean (Beaufort Sea) based on fossil occurrences from the Sagavanirktok and Gubik formations of northern Alaska. Brouwers et al. (1991) reported that Finmarchinella angulata, $P$. limicola and $R$. tuberculata first appeared between $3 \mathrm{Ma}$ and $2 \mathrm{Ma}$ in the Arctic Ocean from the Member $\mathrm{B}$ of northern Greenland. In the northernmost Atlantic, Acanthocythereis $\mathrm{cf}$. dunelmensis, $P$. limicola and $S$. undata first occurred in 2.9-2.8 Ma, and E. concinna, F. angulata, F. logani and $R$. tuberculata first appeared in 1.7-1.5 Ma, based on fossil records from the Tjörnes beds of Iceland (Cronin, 1991).

When comparing both assemblages from the Ogikubo Formation and Plio-Pleistocene Arctic-Atlantic region, $A$. dunelmensis and P. limicola are common. Comparing the external carapace morphology, it is considered that the other six Plio-Pleistocene high-latitude species (E. concinna, F. angulata, F. logani, Munseyella sp. A, R. tuberculata and S. undata) are closely related to six species in the Ogikubo Formation (Elofsonella cf. concinna, Finmarchinella hanaii, F. japonica, Paijenborchella tsurugasakensis, Robertsonites reticuliforma and Semicytherura species (=S. subundata, S. sp. 1, S. sp. 2)). Therefore, occurrences of the two common species and six 


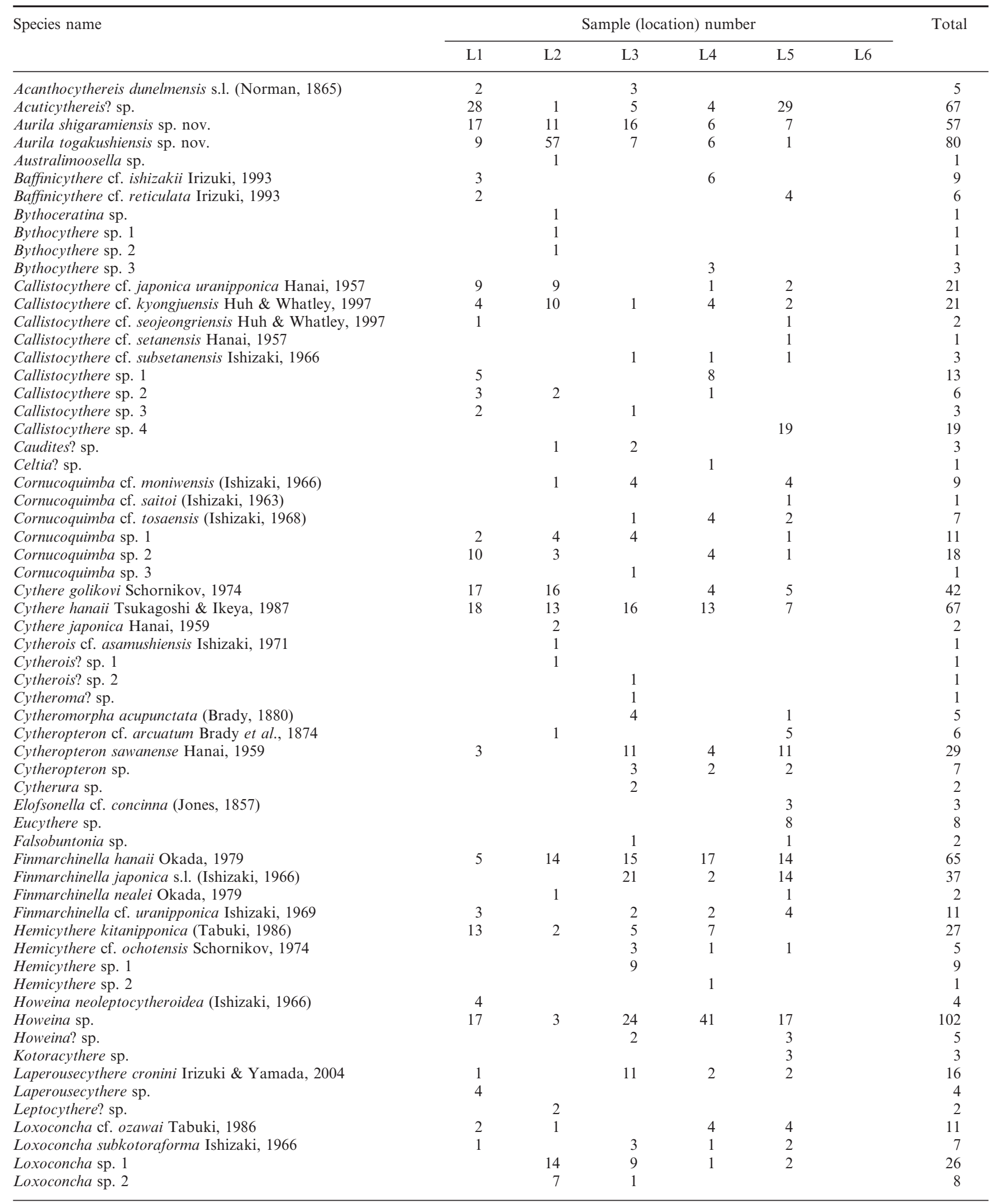

Table 1. Continued. 


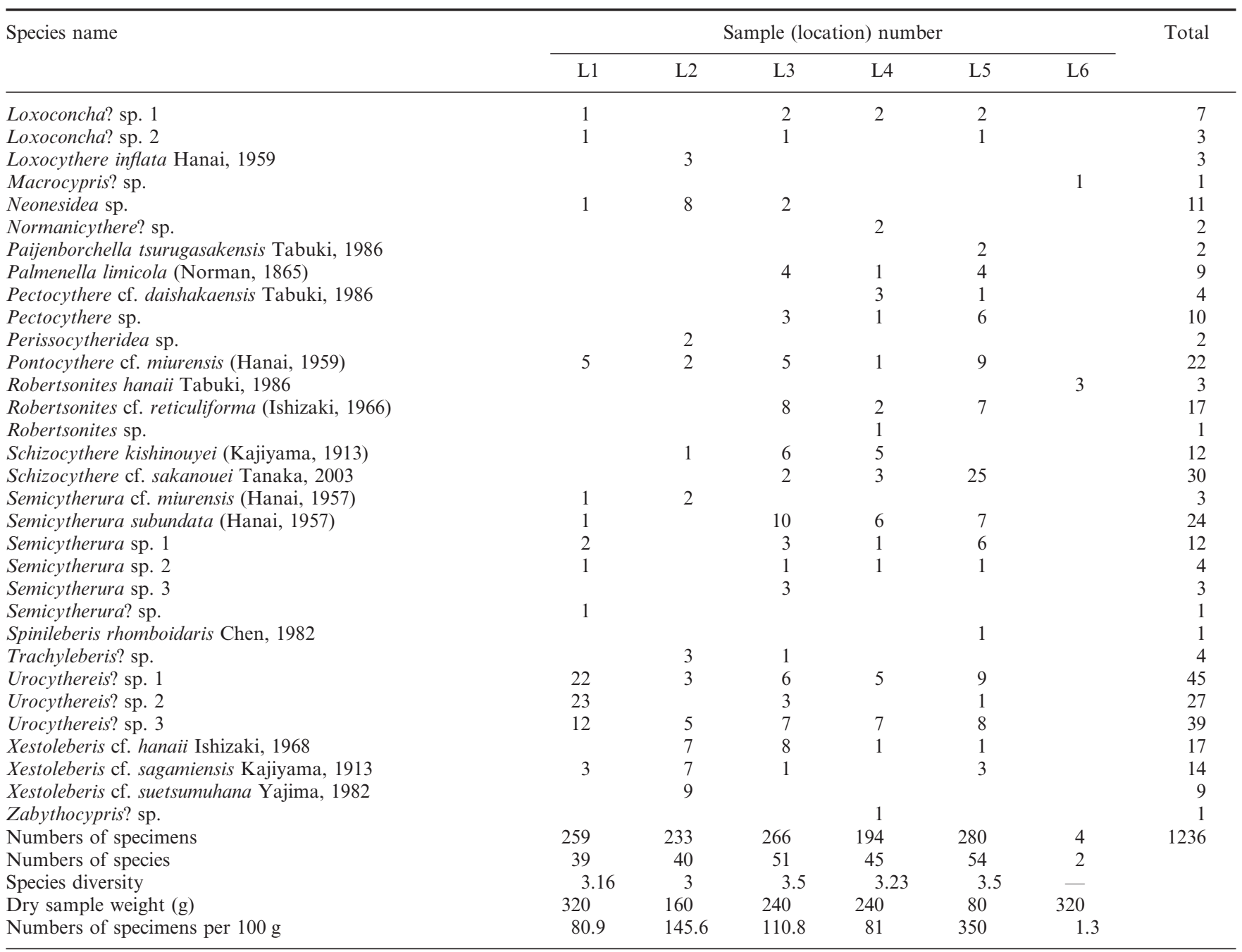

Table 1. List of ostracod species from the Takafu and Ogikubo Formations.

different congeneric species from the Ogikubo Formation (4$3 \mathrm{Ma}$ ) strongly suggest that ostracods in the northwestern Pacific migrated to the northern Atlantic through Arctic seas between $3 \mathrm{Ma}$ and 1.5 Ma, after the Pliocene opening of the Bering Strait in the northern Pacific (5-2 Ma; e.g. Ogasawara, 2001). The fossil occurrences imply that species groups containing these six species had diversified to produce different congeneric species in Arctic-Atlantic seas since the Late Pliocene ( $3 \mathrm{Ma}$ ). This conclusion is supported by results from other palaeobiogeographical analysis of ostracods in, and around, the Arctic (e.g. Cronin et al., 1993; Irizuki, 1994).

Type (1) species from the Ogikubo Formation also contain extinct cryophilic ostracods from the families Hemicytheridae and Cytheruridae, commonly found in Late Pliocene and Pleistocene deposits from the Japan Sea, post-2 Ma (Table 2; Ozawa \& Kamiya, 2005a). A study of the Fujikotogawa Formation by Irizuki (1994) showed that the two genera Hemicythere and Semicytherura had already diversified by the Late Miocene in the Japan Sea (8-7 Ma) in both families. Hemicythere $(H$. kitanipponica) and Semicytherura (S. subundata) occur in common between the Fujikotogawa Formation and the Pliocene
Ogikubo Formation (Table 3). Furthermore, several conferrable or congeneric species of Hemicythere and Semicytherura, occurring in the Ogikubo Formation, are found in Late Pliocene and Pleistocene deposits of the Japan Sea (Ozawa \& Kamiya, 2005a). In contrast, the two genera Laperousecythere and Cornucoquimba from the Ogikubo Formation have few cryophilic species in common with those from post-2 Ma deposits of Japan Sea. Consequently, fossil records of Type (1) species indicate that Laperousecythere and Cornucoquimba had probably not yet diversified in the Japan Sea during the deposition of the Ogikubo Formation (4-3 Ma), but perhaps did so in a slightly later 3-1.5 Ma period (e.g. Ozawa \& Kamiya, 2005a).

Species composition of ostracods in Togakushi differed from other assemblages known from the post-2 Ma Japan Sea (e.g. Cronin \& Ikeya, 1987; Ozawa, 1996), in terms of the content of species in Types (2) and (3). Species of Type (2), such as Callistocythere cf. kyongjuensis, C. cf. seojeongriensis, C. cf. subsetanensis and Schizocythere cf. sakanouei, were congeneric, or comparable with characteristic Miocene species in Japan. They are related closely to species found from Early-Middle Miocene (17-12 Ma) deposits of the southwestern Japan Sea 


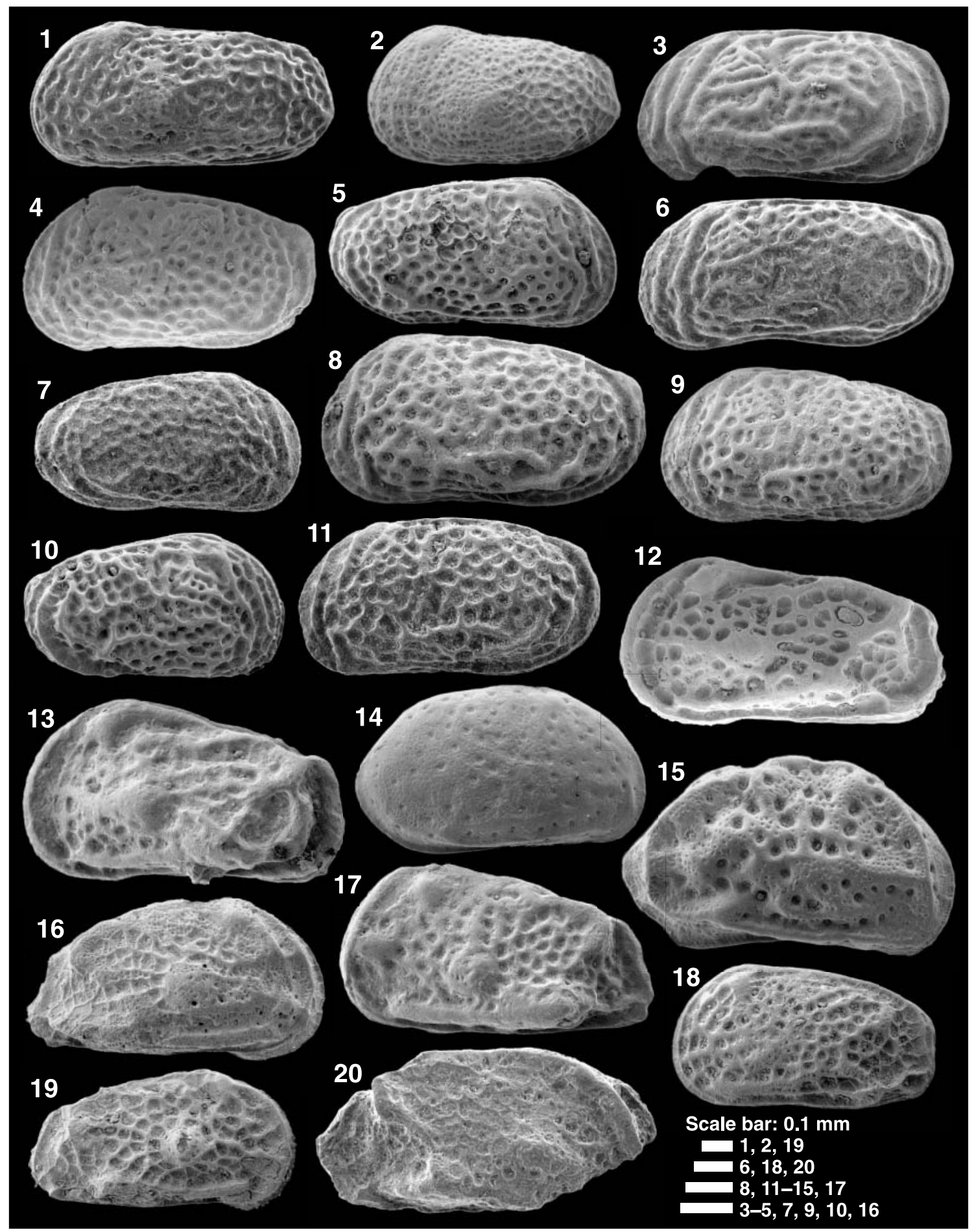

Explanation of Plate 1.

figs 1, 2. Acuticythereis? sp.: 1, adult, carapace, left side, loc. 4; 2, juvenile, left valve, loc. 1. fig. 3. Callistocythere cf. japonica uranipponica Hanai, 1957, adult, left valve, loc. 2. fig. 4. Callistocythere cf. kyongjuensis Huh \& Whatley, 1997, adult, carapace, left side, loc. 2. fig. 5. Callistocythere cf seojeongriensis Huh \& Whatley, 1997, adult, carapace, right side, loc. 3. fig. 6. Callistocythere cf. setanensis Hanai, 1957, adult, left valve, loc. 5. fig. 7. Callistocythere cf. subsetanensis Ishizaki, 1966, adult, carapace, right side, loc. 5. fig. 8. Callistocythere sp. 1, adult, carapace, left side, loc. 4. fig. 9. Callistocythere sp. 3, adult, carapace, left side, loc. 2. fig. 10. Callistocythere sp. 2, adult, carapace, right side, loc. 2. fig. 11. Callistocythere sp. 4, adult, carapace, left side, loc. 5. fig. 12. Cornucoquimba sp. 2, adult, carapace, left side, loc. 2. fig. 13. Cornucoquimba sp. 1, adult, carapace, left side, loc. 1. fig. 14. Cythere golikovi Schornikov, 1974, adult, right valve, loc. 2. fig. 15. Cythere hanaii Tsukagoshi \& Ikeya, 1987, adult, right valve, loc. 2. fig. 16. Finmarchinella hanaii Okada, 1979, adult, right valve, loc. 4. fig. 17. Finmarchinella japonica s.1. (Ishizaki, 1966), adult, left valve, loc. 5. fig. 18. Hemicythere sp. 1, adult, left valve, loc. 3. fig. 19. Laperousecythere cronini Irizuki \& Yamada, 2004, adult, right valve, loc. 3. fig. 20. Laperousecythere sp., adult, right valve, broken anteroventrally, loc. 1. 


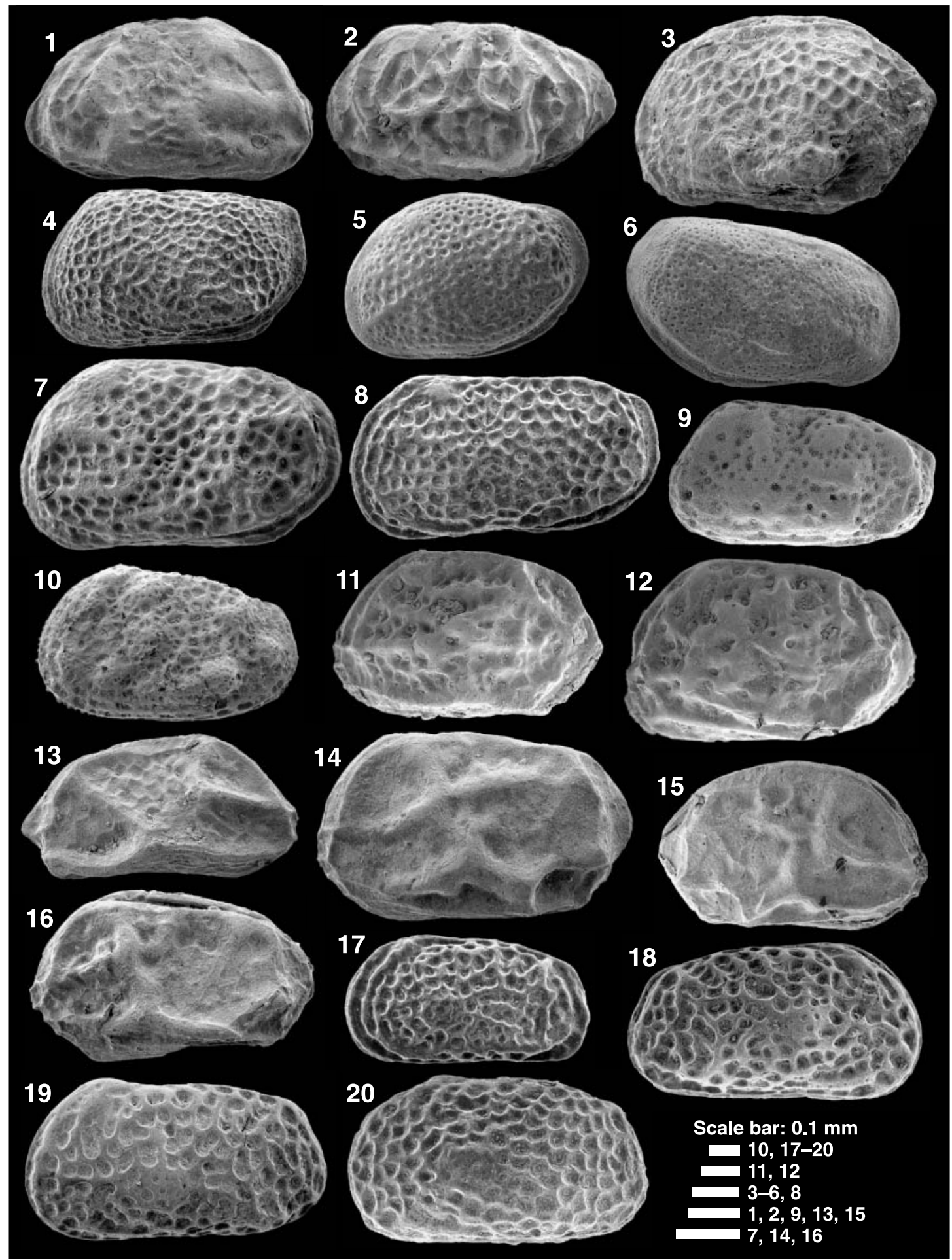

Explanation of Plate 2.

fig. 1. Howeina neoleptocytheroidea (Ishizaki, 1966), adult, right valve, loc. 1. fig. 2. Howeina sp., adult, left valve, loc. 4. fig. 3. Howeina? sp., adult, carapace, left side, loc. 4. fig. 4. Loxoconcha cf. ozawai Tabuki, 1986, adult, carapace, left side, loc. 4. fig. 5. Loxoconcha sp. 1, adult, female, left valve, loc. 2. fig. 6. Loxoconcha sp. 2, adult, male, right valve, loc. 2. fig. 7. Loxoconcha? sp. 1, adult, carapace, left side, loc. 4. fig. 8. Loxoconcha? sp. 2, adult, carapace, left side, loc. 3. fig. 9. Pectocythere sp., adult, carapace, left side, loc. 5. fig. 10. Robertsonites cf. reticuliforma (Ishizaki, 1966), adult, carapace, left side, loc. 5. fig. 11. Schizocythere kishinouyei (Kajiyama, 1913), adult, carapace, left side, loc. 2. fig. 12. Schizocythere cf. sakanouei Tanaka, 2003, adult, carapace, left side, loc. 5. fig. 13. Semicytherura subundata (Hanai, 1957), adult, right valve, loc. 5. figs 14 , 15. Semicytherura sp. 1: 14, adult, left valve, loc. 5; 15, adult, carapace, right side, loc. 5. fig. 16. Semicytherura sp. 2, adult, carapace, left side, loc. 4. fig. 17. Urocythereis? sp. 1, adult, left valve, loc. 5. figs 18, 19. Urocythereis? sp. 2: 18, adult, carapace, right side, loc. 1; 19, adult, left valve, loc. 1. fig. 20. Urocythereis? sp. 3 , adult, carapace, left side, loc. 5. 


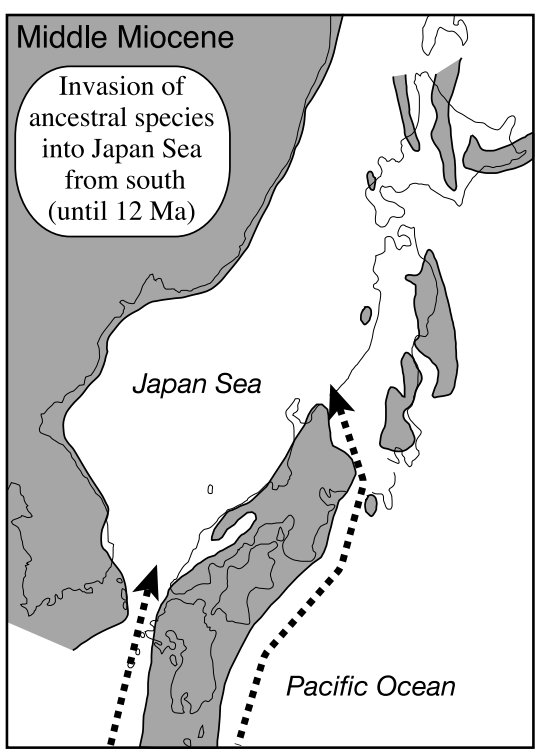

(a)

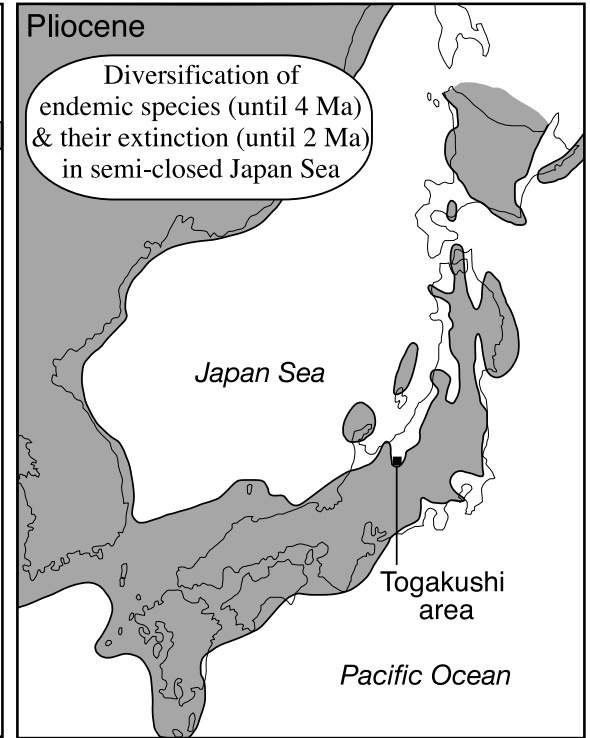

(b)

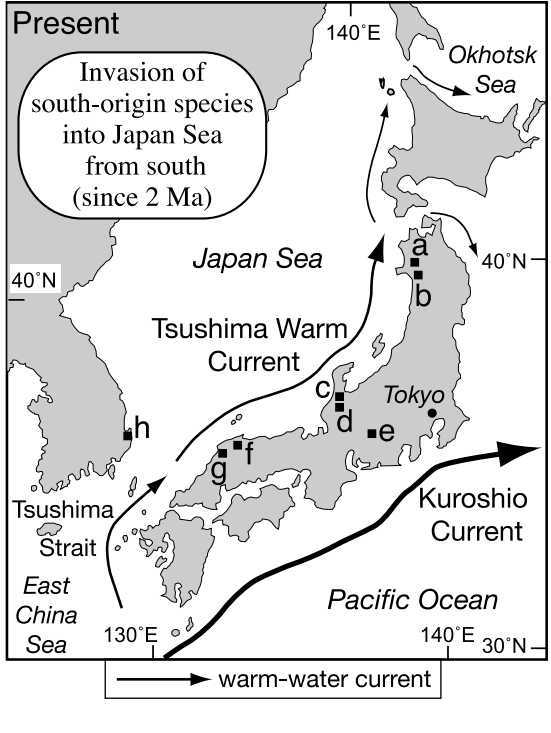

(c)

Fig. 3. Maps for the Japanese Islands of the two geological periods - (a) Middle Miocene in 13-12 Ma, (b) Late Pliocene around 3 Ma, simplified from Iijima \& Tada (1990) - showing the event information for Types (2) and (3) species. (c) Map for the Japanese Islands of the present, illustrating the modern warm-current system and localities of Miocene-Pleistocene strata appearing in the text; a, Fujikotogawa Fm.; b, Sasaoka Fm.; c, Omma Fm.; d, Sunagozaka Fm.; e, Mizunami \& Iwamura Gps; f, Fujina Fm.; g, Omori Fm.; h, Yeonil Gp. Fm: Formation; Gp.: Group.

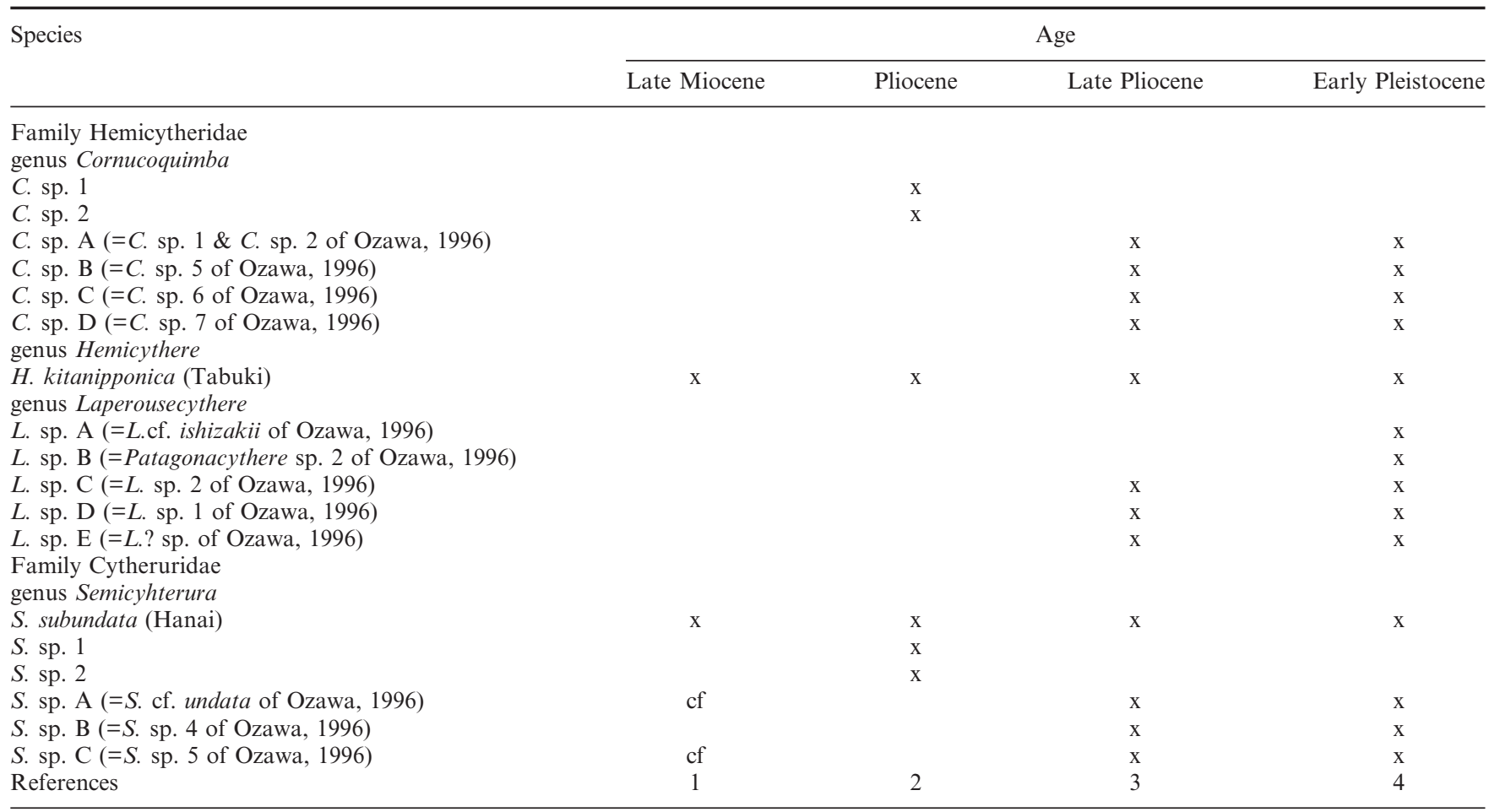

Based on data from this study and published studies - (1) Fujikotogawa Fm.: Irizuki (1994); (2) Ogikubo Fm. (4-3 Ma): this study; (3) Sasaoka Fm. (2 Ma): Ishizaki \& Matoba (1985), Ishii \& Kamiya (unpublished data); (4) Omma Fm.: Ozawa (1996), Ozawa \& Kamiya (2005b). cf, occurrence of conferrable species; Fm., Formation.

Table 2. Summary of fossil occurrences in two Families Hemicytheridae and Cytheruridae of Type (1) species and their related-species from the Ogikubo Formation and Late Miocene-Early Pleistocene strata of Japan Sea. 


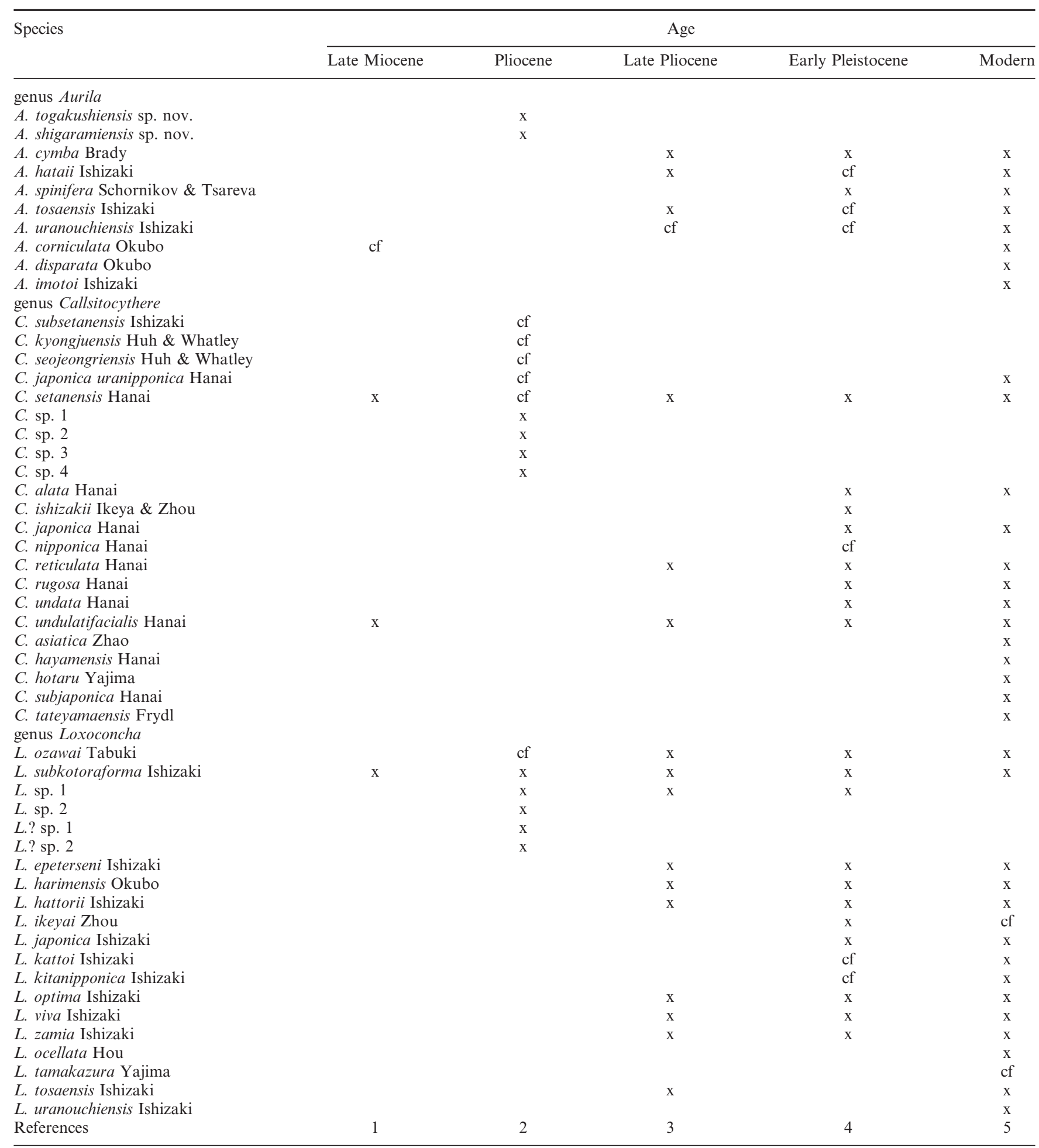

Based on data from this study and published studies - for 1-4 see Table 2; (5) modern Japan Sea: Ikeya \& Suzuki (1992), Tsukawaki et al. (1997, 1998, 1999, 2000, 2001), Kamiya et al. (2001). cf, occurrence of conferrable species.

Table 3. Summary of fossil and modern ostracod occurrences of species in three genera Aurila, Callistocythere and Loxoconcha of Types (2) and (3) with their related species from the Ogikubo Formation, Late Miocene-Early Pleistocene strata of Japan Sea, and modern Japan Sea. 
coast - the Sunagozaka Formation (17-16 Ma; Yanagisawa, 1999; Tanaka et al., 2004), the Yeonil Group (16 Ma; Huh \& Paik, 1992; Huh \& Whatley, 1997; Akimoto et al., 1999) and the Omori and Fujina formations (15-12 Ma; Tanaka et al., 2002; Tanaka, 2003) (Fig. 3c).

The Togakushi Pliocene species Callistocythere cf. kyongjuensis, C. cf. seojeongriensis, C. cf. subsetanensis and Schizocythere cf. sakanouei are very similar, closely related but distinct to the formally described Miocene species (Table 3). Differences relate to the degree of carapace roundness, as well as reticulation patterns and the carapace ridge directions. Type (3) species, such as Aurila togakushiensis, A. shigaramiensis and Loxoconcha sp. 2 , are probably endemic to the Pliocene Japan Sea because there are no records from the Miocene, Pleistocene and modern faunas in, and around, the Japan Sea.

Types (2) and (3) can also be characterized by the presence of taxa of southern origin, particularly species from Aurila, Callistocythere and Loxoconcha. These genera show high species diversity from the Pliocene to the present throughout areas affected by the modern warm Kuroshio Current of the east Asian western Pacific. This assemblage occurs along central to southwestern Japan, the Ryukyu Islands and Southeast Asia (Hanai et al., 1977, 1980; Ishizaki, 1983; Ozawa et al., 1995; Zhou, 1995; Nakao et al., 2001; Tabuki, 2001; Tanaka \& Ikeya, 2002). It is considered that ancestor species would have migrated to the southern Japan Sea from the Pacific from the Middle Miocene (12 Ma, Tanaka et al., 2002; Fig. 3a).

One species, Callistocythere kyongjuensis, has also been reported from the Early Miocene Mizunami and Iwamura groups (18 Ma; Irizuki et al., 2004) along the Pacific coast, central Japan (Fig. 3c). Thus, their ancestral species must have diversified in the nearly land-locked Japan Sea between the Middle Miocene-Early Pliocene (12-4 Ma, Fig. 3b; Iijima \& Tada, 1990; Chinzei, 1991), and produced different congeneric species there. Some species of Callistocythere were also reported from the Late Miocene (8-7 Ma) Japan Sea coast (Irizuki, 1994), but specific numbers were much lower than those of the Ogikubo Formation (Table 3).

Genera of southern origin in Types (2) and (3) also contain species probably endemic to the Pliocene Japan Sea (Table 3). These species did not extend their distribution to other areas and have persisted within the restricted sea of the Togakushi region until the Late Pliocene (3 Ma). Their extinction after $3 \mathrm{Ma}$ was probably caused by the climatic cooling of the Japan Sea during the 2.8-2.5 Ma glacial periods (Cronin et al., 1994; Amano, 2001; Sato et al., 2003; Yamada et al., 2005). This occurred with Late Pliocene intensification of Northern Hemisphere glaciations in high-latitude Arctic, North Atlantic and North Pacific oceans (e.g. Raymo et al., 1989; Kleiven et al., 2002; Sato et al., 2004).

The failure of both Types (2) and (3) to extend their distribution even within the Japan Sea, post-3 Ma, also indicates that some geographical or oceanic environmental barriers dictated species distribution in, and around the Togakushi area. The palaeotopography of the Japan Sea during the Pliocene shows the Togakushi region lying at the end of a 100-km long narrow inlet open only at its northern extent (e.g. Amano \& Karasawa, 1993; Fig. 3b). Therefore, the distinct topography may have provided a sufficient barrier in itself to isolate the ostracods of the Togakushi area.

A comparison of species occurrences of Aurila, Callistocythere and Loxoconcha from the Ogikubo Formation show only a few common species with those assemblages from other post-2 Ma strata of the Japan Sea coast (Table 3). Furthermore, in the Late Pliocene and Pleistocene many species were reported from Pacific from three genera such as Aurila spinifera, Callistocythere alata and Loxoconcha japonica, first appeared post-2 Ma in the Japan Sea (Table 3). Species compositions for the three genera from the Japan Sea and Pacific coasts have remained similar since the Early Pleistocene (e.g. Ozawa \& Kamiya, 2001). The southern strait (=Palaeo-Tsushima Strait) of the Japan Sea remained almost closed until $3 \mathrm{Ma}$ (Iijima \& Tada, 1990; Fig. 3b). In the Late Pliocene (3-2 Ma), this strait re-opened a few times, but opened more frequently from the Early Pleistocene in response to interglacial episodes (Koizumi, 1992; Kitamura \& Kimoto, 2004), allowing warm current flow into the Japan Sea at these times as in the area in the present setting (Fig. 3c; Ozawa \& Kamiya, 2001, 2005a, b; Yamada et al., 2002, 2005; Irizuki et al., 2007). Therefore, southern species of Aurila, Callistocythere and Loxoconcha invaded the Japan Sea from the Pacific since $2 \mathrm{Ma}$, giving rise to many species of these three genera, which inhabit the modern Japan Sea (Table 3).

\section{CONCLUSIONS}

The Pliocene Takafu and Ogikubo formations (4-3 Ma) yielded significant ostracods containing three types of extinct species. These are useful to investigate the origins of high-latitude (Arctic-Atlantic) species and the Japan Sea endemic species, together with the post-Miocene history of their speciationextinction and migration. Three types were defined. Type (1) included cryophilic ostracods in common with, or closely-related to species described from the Late Plio-Pleistocene Japan Sea. These were closely related to, or comparable with high-latitude species previously reported from the Arctic and northern Atlantic oceans. Their occurrences in the Ogikubo Formation strongly suggest an ostracod migration from the northwestern Pacific to the northern Atlantic through Arctic seas since the Late Pliocene ( $3 \mathrm{Ma}$ ) after the opening of the Bering Strait, and their diversification to produce congeneric species in high latitudes.

Types (2) and (3) faunas differed from assemblages known from the Late Pliocene-Pleistocene Japan Sea. Type (2) species were closely related to, or comparable with, characteristic Miocene species from the southwestern Japan Sea, and Type (3) species were probably endemic to the Pliocene Japan Sea. Types (2) and (3) contained genera originating from the south, which showed high species diversity in areas influenced by the modern warm Kuroshio Current along the western Pacific coast in East-Southeast Asia. Their ancestral species had migrated into the Japan Sea from the Pacific from the Middle Miocene (12 Ma). They diversified in the mostly land-locked Japan Sea until the Early Pliocene (4 Ma) and produced different congeneric species there. Subsequently, species of Types (2) and (3) did not extend their areas of distribution and became extinct during the Late Pliocene (3-2 Ma). 


\section{SYSTEMATIC DESCRIPTIONS (BY HIROKAZU OZAWA)}

Two new species are described herein. All type specimens are identified by numbers with the prefix MPC (Micropaleontology Collection, National Museum of Nature and Science, Tokyo). The type locality of the two new species is location 2 of this study (Fig. 1), and is from the same locality (Loc. 30) of Nagamori (1998).

\section{Superfamily Cytheroidea Baird, 1850 \\ Family Hemicytheridae Puri, 1953 \\ Subfamily Hemicytherinae Puri, 1953 \\ Genus Aurila Pokorny, 1955 \\ Aurila togakushiensis sp. nov.}

(Pl. 3, figs 1-10)

Derivation of name. Togakushi, the provincial name of the type locality of this species.

Diagnosis. Carapace large and heavily calcified; almond-shaped left valve, subtrapezoidal right valve. Surface covered with distinct round fossae in median area with numerous fine pits in anterior and posterior areas. Fossae arranged in slightly concentric rows subparallel to ventral margin.

Holotype. Male, right valve, MPC-04822, from location 2 (P1. 3, figs 2, 5).

Paratypes. Male, left valve, MPC-04823 (Pl. 3, figs 1, 6). Female, complete carapace, MPC-04824 (P1. 3, fig. 3). Female, right valve, MPC-04825 (P1. 3, figs 4, 7). All specimens are from location 2.

Type locality. Location 2, the Pliocene Ogikubo Formation, an exposure at the river bed of the Susobana River, Nakagumi, Nagano City, Nagano Prefecture, central Japan (Lat. $36^{\circ} 40.1^{\prime} \mathrm{N}$, Long. $\left.138^{\circ} 05.3^{\prime} \mathrm{E}\right)$.

Description. Valves large and asymmetrical; in lateral view, almond-shaped left valve, subtrapezoidal right valve. Left valve higher and overreaches right valve dorsally. Maximum height near mid-length in left valve, at one-third of valve length in right valve. Maximum length near mid-height. Anterior margin smooth, broadly and obliquely rounded. Dorsal margin slightly arched. Ventral margin slightly concave at anterior midlength. Posterior margin with a nearly straight section above a postero-caudal process.

Carapace surface punctuated with round shallow fossae in median area, with numerous fine pits in anterior, posterior and dorsal areas. Fossae arranged in slightly concentric rows subparallel to ventral margin. Faint reticulation developed along antero- and postero-marginal areas. One weak postero-ventral sub-marginal crest. Eye tubercles inconspicuous. Carapace surface covered with scattered normal-type pore.

Hingement: amphidont; in right valve, anterior round element, shallow sub-rounded socket, short, smooth median groove and curved subquadrate posterior element; in left valve, deep anterior socket, anterior round tooth, short, smooth median bar and posterior subquadrate socket with small, round subordinate element. Four adductor muscle scars in a vertical line; upper and lower single, and central two divided into two, lowermost single one elongate; three sub-round frontal scars in oblique row. Narrow vestibules anteriorly and posteriorly. Inner lamella broad.

Sexual dimorphism distinct. Carapace of male more slender and longer than female in lateral view. Outline of ventral margin in male is slightly concave a quarter of the way along valve in right valve.

Dimensions (mm). $\mathrm{L}=0.86, \mathrm{H}=0.51$ (holotype, male, right valve, MPC-04822); $\mathrm{L}=0.93, \mathrm{H}=0.55$ (male, left valve, MPC-04823); $\mathrm{L}=0.87, \mathrm{H}=0.54$ (female, carapace, MPC-04824); $\mathrm{L}=0.84$, $\mathrm{H}=0.51$ (female, right valve, MPC-04825); $\mathrm{L}=0.65, \mathrm{H}=0.40$ (A-1 juvenile, right valve, MPC-04826); $\mathrm{L}=0.72, \mathrm{H}=0.44$ (A-1 juvenile, left valve, MPC-04827).

Occurrence. Five samples, limited to the Pliocene Ogikubo Formation (locations 1-5).

Remarks. This species resembles Aurila uranouchiensis described by Ishizaki (1968) from Recent sediments in Uranouchi Bay, southwest Japan, in general carapace morphology. However, it differs by its larger valve size, valve outline and the nature of the valve surface and crest. The general outline of this species is elongate, and the outline of the posterior margin is rounded. The fossae on the surface of this species are weak and shallow, and the ventral crest is indistinct. Faint reticulation is developed along the antero- and postero-marginal areas in this species, and the valve surface is covered by fine pits in the anterior, posterior and dorsal areas.

This species has variability in the development of faint reticulation in the antero- and postero-marginal areas and one weak postero-ventral sub-marginal ridge.

\section{Aurila shigaramiensis sp. nov.} (P1. 3, figs 11-18)

Derivation of name. Shigarami, the old village name near the type locality of this species.

Diagnosis. Carapace medium-sized and heavily calcified; almond-shaped left valve, subtrapezoidal right valve. Surface covered with round and small fossae in median area with numerous fine pits in anterior, posterior and dorsal areas. Round fossae in straight rows running subparallel to ventral margin. One narrow and weak crest subparallel to ventral margin.

Holotype. Female, left valve, MPC-04828, from location 2 (Pl. 3, fig. 12).

Paratypes. Male, right valve, MPC-04829 (Pl. 3, fig. 11). Male, right valve, MPC-04830 (Pl. 3, figs 13, 14). Female, left valve, MPC-04831 (Pl. 3, fig. 16). Female, complete carapace, MPC-04832 (Pl. 3, figs 17, 18). Male, left valve, MPC-04833 (Pl. 3, fig. 15). All specimens from location 2, except MPC-04830 from location 3 . 


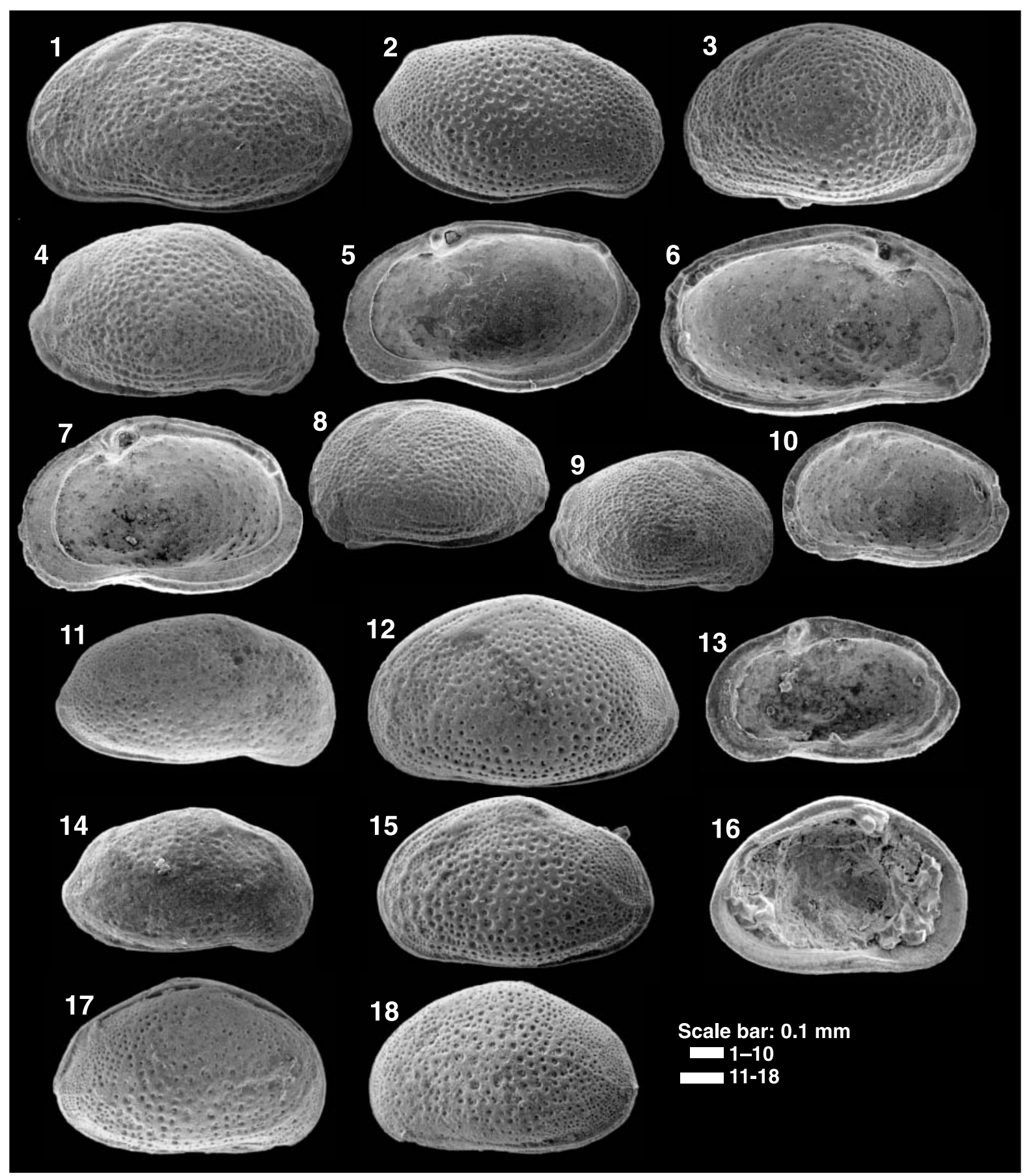

Explanation of Plate 3.

figs 1-10. Aurila togakushiensis Ozawa sp. nov., all specimens from loc. 2: 1, male, left valve (paratype, MPC-04823); 2, male, right valve (holotype, MPC-04822); 3, female, carapace, left side (paratype, MPC-04824); 4, female, right valve (paratype, MPC-04825); 5, male, right valve from inside (holotype, MPC-04822); 6, male, left valve from inside (paratype, MPC-04823); 7, female, right valve from inside (paratype, MPC-04825); 8, A-1 juvenile, right valve (MPC-04826); 9, A-1 juvenile, left valve (MPC-04827); 10, A-1 juvenile, right valve from inside (MPC-04826). figs 11-18. Aurila shigaramiensis Ozawa sp. nov., specimens 11, 12, 15-18 from loc. 2, and 13, 14 from loc. 3: 11, male, right valve (paratype, MPC-04829); 12, female, left valve (holotype, MPC-04828); 13, male, right valve from inside (paratype, MPC-04830); 14, male, right valve (paratype, MPC-04830); 15, male, left valve (paratype, MPC-04833); 16, female, left valve from inside (paratype, MPC-04831); 17, female, carapace, right side (paratype, MPC-04832); 18, female, carapace, left side (paratype, MPC-04832). 
Type locality. Location 2, the Pliocene Ogikubo Formation, an exposure at the river bed of the Susobana River, Nakagumi, Nagano City, Nagano Prefecture, central Japan (Lat. $36^{\circ} 40.1^{\prime} \mathrm{N}$, Long. $138^{\circ} 05.3^{\prime} \mathrm{E}$ ).

Description. Valves medium-sized and asymmetrical; in lateral view, almond-shaped left valve, subtrapezoidal right valve. Left valve higher and overreaches right valve dorsally. Maximum height near mid-length in left valve, at one-third of valve length in right valve. Maximum length at one-third of valve height. Anterior margin smooth, broadly and obliquely rounded. Dorsal margin of left valve slightly arched with an obtuse angle at highest point. Dorsal margin of right valve slightly arched. Ventral margin slightly concave at anterior middle. Posterior margin with slightly curved section above postero-caudal process.

Carapace surface covered with round shallow-fossae in median area with numerous very fine pits in anterior, posterior and dorsal areas. Round fossae in slightly concentric rows subparallel to ventral margin. Faint reticulation developed along antero-marginal area. One faint crest in posteroventral area running posteriorly. Eye tubercles inconspicuous. Carapace surface covered with scattered normal-type pore.

Hingement: amphidont; in right valve, anterior round element, shallow sub-round socket, short smooth median groove and curved subquadrate posterior element; in left valve, deep anterior socket, anterior round tooth, short smooth median bar and posterior subquadrate socket. Four adductor muscle scars in a vertical row; upper and lower single, and central two divided into two, and lowermost single one elongate; three sub-round frontal scars arranged in gentle curve with convex side to posterior. Narrow vestibules anteriorly and posteriorly. Inner lamella broad.

Sexual dimorphism distinct. Carapace of male more slender and longer than female in lateral view. Outline of ventral margin in male slightly concave a quarter of the way along anterior right valve.

Dimensions (mm). $\mathrm{L}=0.73, \mathrm{H}=0.45$ (holotype, female, left valve, MPC-04828); $\mathrm{L}=0.63, \mathrm{H}=0.35$ (male, right valve, MPC-04829); $\mathrm{L}=0.56, \mathrm{H}=0.33$ (male, right valve, MPC-04830); $\mathrm{L}=0.61$, $\mathrm{H}=0.40$ (female, left valve, MPC-04831); $\mathrm{L}=0.63, \mathrm{H}=0.39$ (female, carapace, MPC-04832); $\mathrm{L}=0.61, \mathrm{H}=0.39$ (male, left valve, MPC-04833).

Occurrence. Only from the Pliocene Ogikubo Formation, from five samples (locations 1-5).

Remarks. This species is similar to Aurila tosaensis described by Ishizaki (1968) from Recent sediments in Uranouchi Bay, southwest Japan, in general carapace morphology. However, it differs from $A$. tosaensis by its larger valve size, valve outline and the nature of the valve surface and crest. The lateral outline of this species is triangular, and the dorsal margin is arched. The outline of the posterior margin and caudal process of this species is rounded. The fossae on the surface of the present species are weak and small, and the ventral crest is not distinct and not angular. The valve surface of the present species is covered by very fine pits in the anterior, posterior and dorsal areas.
This species has variability in the development of round fossae in the median area, faint reticulation in the anterior area, and one faint crest in the posterior area.

\section{ACKNOWLEDGEMENTS}

The authors would like to thank Y. Tanimura (National Museum of Nature and Science, Tokyo) for assistance with various aspects of preparing the manuscript. Thanks are also due to T. Kamiya, T. Ishii, T. Sato (Kanazawa University), A. Tsukagoshi (Shizuoka University) and T. Irizuki (Shimane University) for help with ostracod identification. Thanks go to R. J. Smith (Lake Biwa Museum) for correcting the early draft, and K. Hachiya and Y. Mizuno (Tokai Fossil Society) for valuable information on fossil occurrences in Togakushi. Constructive reviews with valuable suggestions by $M$. Yasuhara (Smithsonian's Museum of Natural History) and an anonymous reviewer, and editing by F. J. Gregory, helped to improve the manuscript. This study was supported by Grant-in-Aid for JSPS Research Fellow for Young Scientists (6372 to H. Ozawa).

\section{Manuscript received 31 July 2006 Manuscript accepted 12 September 2008}

\section{REFERENCES}

Akimoto, K., Ureshino, M., Sugiura, M., Irizuki, T., Yamaji, A., Jung, K.K. \& Lee, Y.G. 1999. Paleoenvironment reconstructed by the Miocene benthic foraminiferal assemblages in the Pohang area, Southeast Korea. Journal of Geological Society of Japan, 105: 391-409 [in Japanese with English abstract].

Amano, K. 2001. Pliocene molluscan fauna of Japan Sea borderland and the paleoceanographic conditions. Biological-Science (Tokyo), 53: 178-184 [in Japanese].

Amano, K. 2005. Migration and adaptation of late Cenozoic cold-water molluscs in the North Pacific. In: Elewa, A.M.T. (Ed.), Migration of organisms: Climate, Geography, Ecology. Springer-Verlag, Berlin, $127-150$.

Amano, K. \& Karasawa, S. 1993. Molluscan fauna and paleoenvironment of the Pliocene Ogikubo Formation in the northern part of Nagano Prefecture, central Japan. Journal of Geography (Chigaku-Zassi), 102: 572-582 [in Japanese, English abstract].

Blow, W.H. 1969. Late Middle Eocene to Recent planktonic foraminiferal biostratigraphy. In: Bronniman, P. \& Renz, H.H. (Eds), Proceedings of the First International Conference on Planktonic Microfossils (Geneva, 1967), 1. E.J. Brill, Leiden, 199-421.

Boomer, I., Horne, D.J. \& Slipper, I.J. 2003. The use of ostracodes in paleoenvironmental studies or what can you do with ostracode shell? In: Park, L.E. \& Smith, A.J. (Eds), Bridging the gap: trends in the ostracode biological and geological sciences. The Paleontological Society Papers, 9. Yale University, New Haven, 153-179.

Brouwers, E.M. 1994. Late Pliocene paleoecologic reconstructions based on ostracode assemblages from the Sagavanirktok and Gubik Formations, Alaskan North Slope. Arctic, 47: 16-33.

Brouwers, E.M., Jørgensen, N.O. \& Cronin, T.M. 1991. Climatic significance of the ostracode fauna from the Pliocene Kap København Formation, north Greenland. Micropaleontology, 37: 245-267.

Chinzei, K. 1991. Late Cenozoic zoogeography of the Sea of Japan area. Episodes, 14: 231-235.

Cronin, T.M. 1991. Late Neogene marine Ostracoda from Tjörnes, Iceland. Journal of Paleontology, 65: 767-794.

Cronin, T.M. \& Ikeya, N. 1987. The Omma Manganji ostracode fauna (Plio-Pleistocene) of Japan and the zoogeography of circumpolar species. Journal of Micropalaeontology, 6: 65-88.

Cronin, T.M. \& Raymo, M.E. 1997. Orbital forcing of deep-sea benthic species diversity. Nature, 385: 624-627.

Cronin, T.M., Whatley, R., Wood, A., Tsukagoshi, A., Ikeya, N., Brouwers, E.M. \& Briggs, J.r.W.M. 1993. Microfaunal evidence 
for elevated Pliocene temperatures in the Arctic Ocean. Paleoceanography, 8: 161-173.

Cronin, T.M., Kitamura, A., Ikeya, N., Watanabe, M. \& Kamiya, T. 1994. Late Pliocene climate change 3.4-2.3 Ma: paleoceanographic record from the Yabuta Formation, Sea of Japan. Palaeogeography, Palaeoclimatology, Palaeoecology, 108: 437-455.

Cronin, T.M., DeMartino, D.M., Dwyer, G.S. \& Rodriguez-Lazaro, J. 1999. Deep-sea ostracode species diversity: response to late Quaternary climate changes. Marine Micropaleontology, 37: 231-249.

Hanagata, S. 2003. Miocene-Pliocene foraminifera from the Niigata oil-fields region, northeastern Japan. Micropalaeontology, 49: 293-340.

Hanai, T., Ikeya, N., Ishizaki, K., Sekiguchi, Y. \& Yajima, M. 1977. Checklist of Ostracoda from Japan and its adjacent seas. University Museum, University of Tokyo Bulletin, 12: 1-119.

Hanai, T., Ikeya, N. \& Yajima, M. 1980. Checklist of Ostracoda from Southeast Asia. University Museum, University of Tokyo Bulletin, 17: $1-242$.

Hoshi, H. \& Takahashi, M. 1999. Miocene counterclockwise rotation of Northeast Japan: a review and new model. Bulletin of Geological Survey of Japan, 50: 3-16.

Huh, M. \& Paik, K.H. 1992. Miocene Ostracoda from the Seojeongri Area, Pohang Basin, Korea. Journal of Geological Society of Korea, 28: $273-283$.

Huh, M. \& Whatley, R. 1997. New species of Miocene cytheracean Ostracoda from the Pohang Basin, SE Korea. Journal of Micropalaeontology, 16: 31-40.

Iijima, A. \& Tada, R. 1990. Evolution of Tertiary sedimentary basins of Japan in reference to opening of the Japan Sea. Journal of Faculty of Sciences, University of Tokyo, Sec II, 22: 121-171.

Ikeya, N. \& Suzuki, C. 1992. Distributional patterns of modern ostracodes off Shimane Peninsula, southwestern Japan Sea. Report of Faculty of Sciences, Shizuoka University, 26: 91-137.

Irizuki, T. 1989. Fossil ostracode assemblages from the Pliocene Sasaoka Formation, Akita City, Japan - with reference to sedimentological aspects. Transactions and Proceedings of Palaeontological Society of Japan, New Series, 156: 296-318.

Irizuki, T. 1993. Morphology and taxonomy of some Japanese hemicytherin Ostracoda - with particular reference to ontogenetic changes of marginal pores. Transactions and Proceedings of Palaeontological Society of Japan, 170: 186-211.

Irizuki, T. 1994. Late Miocene ostracods from the Fujikotogawa Formation, northern Japan - with reference to cold water species involved with trans-Arctic interchange. Journal of Micropalaeontology, 13: 3-15.

Irizuki, T. 1996. Lithology and Ostracoda from the Pliocene Tentokuji Formation along the southern marginal area of Mt. Taiheizan, Akita Prefecture, Northeast Japan. Bulletin of Aichi University of Education (Natural Science), 45: 23-32.

Irizuki, T., Yamada, K., Maruyama, T. \& Ito, H. 2004. Paleoecology and taxonomy of early Miocene Ostracoda and paleoenvironment of the eastern Setouchi Province, central Japan. Micropaleontology, 50: $105-147$.

Irizuki, T., Kusumoto, M., Ishida, K. \& Tanaka, Y. 2007. Sea-level change and water structures between 3.5 and $2.8 \mathrm{Ma}$ in the central part of the Japan Sea Borderland: Analysis of fossil Ostracoda from the Pliocene Kuwae Formation, central Japan. Palaeogeography, Palaeoclimatology, Palaeoecology, 245: 421-433.

Ishizaki, K. 1968. Ostracodes from Uranouchi Bay, Kochi Prefecture, Western Honshu, Japan. Tohoku University, Science Report, 2nd series, 37: 1-45.

Ishizaki, K. 1983. Ostracoda from the Pliocene Ananai Formation, Shikoku, Japan - Description. Transactions and Proceedings of Palaeontological Society of Japan, 131: 135-158.

Ishizaki, K. \& Matoba, Y. 1985. Excursion 5, Akita (Early Pleistocene cold, shallow water Ostracoda). In: Ikeya, N. (Ed.), Guidebook of Excursions for 9th International Symposium of Ostracoda, Shizuoka. Organising committee of 9th ISO, Shizuoka, 1-12.

Kamiya, T., Ozawa, H. \& Obata, M. 2001. Quaternary and Recent marine Ostracoda in Hokuriku district, the Japan Sea coast. In: Ikeya, N. (Ed.), Field Excursion Guidebook; 14th International Symposium of
Ostracoda, Shizuoka. Organising Committee of 14th ISO, Shizuoka, 73-106.

Kitamura, A. \& Kimoto, K. 2004. Reconstruction of the southern channel of the Japan Sea at 3.9-1.0 Ma. Quaternary Research (Daiyonki-Kenkyu), 43: 417-434 [in Japanese, English abstract].

Kleiven, H., Jansen, E., Fronval, T. \& Smith, T. 2002. Intensification of Northern Hemisphere glaciations in the circum Atlantic region (3.5$2.4 \mathrm{Ma}$ ) - ice-rafted detritus evidence. Palaeogeography, Palaeoclimatology, Palaeoecology, 184: 213-223.

Koizumi, I. 1992. Biostratigraphy and paleoceanography of the Japan Sea based on diatoms: ODP Leg 127. In: Tsuchi, R. \& Ingle, J.C. Jr (Eds), Pacific Neogene: environment, evolution, and events. University of Tokyo Press, Tokyo, 15-24.

Motoyama, I. \& Nagamori, H. 2006. Radiolarians from the Pliocene of the Hoksuhin district, Nagano Prefecture Japan. Journal of Geological Society of Japan, 112: 541-548 [in Japanese with English abstract].

Nagamori, H. 1998. Molluscan fossil assemblages and paleoenvironment of the Pliocene strata in the Hokushin district, Nagano Prefecture, central Japan. Earth Sciences (Chikyu-Kagaku), 52: 5-25 [in Japanese with English abstract].

Nagamori, H., Furukawa, R. \& Hayatsu, K. 2003. Geology of the Togakushi district. Quadrangle Series, 1: 50,000. Geological Survey of Japan, AIST, Tsukuba, 1-109 [in Japanese with English abstract].

Nakao, Y., Tanaka, G. \& Yamada, S. 2001. Pleistocene and Living marine Ostracoda in Shizuoka district, Japan. In: Ikeya, N. (Ed.), Field Excursion Guidebook for the 14th International Symposium of Ostracoda, Shizuoka. Organising committee of 14th ISO, Shizuoka, $127-147$.

Ogasawara, K. 2001. Notes on palaeoceanographic background for change of the Japanese Cenozoic molluscan faunas. Biological-Science (Tokyo), 53: 185-191 [in Japanese].

Otofuji, Y., Kambara, A., Matsuda, T. \& Nohdam, S. 1994. Counterclockwise rotation of Northeast Japan: Paleomagnetic evidence for regional extent and timing of rotation. Earth and Planetary Science Letters, 121: 503-518.

Ozawa, H. 1996. Ostracode fossils from the late Pliocene to early Pleistocene Omma Formation in the Hokuriku district, central Japan. Science Report of Kanazawa University, 41: 77-115.

Ozawa, H. 2003a. Japan Sea ostracod assemblages in surface sediments: their distribution and relationships to water mass properties. Paleontological Research, 7: 257-274.

Ozawa, H. 2003b. Cold-water ostracod fossils from the southern and eastern margins of the Japan Sea. Journal of Geological Society of Japan, 109: 459-465.

Ozawa, H. 2004. Okhotsk Sea ostracods in surface sediments: depth distribution of cryophilic species relative to oceanic environment. Marine Micropaleontology, 53: 245-260.

Ozawa, H. 2006. An overview of the geographical distribution and ecological significance of species in the three families of cryophilic ostracods (Crustacea: Ostracoda) in and around the Japan Sea - with special reference to distribution of species in relation to water temperature-salinity ranges. Taxa, Proceedings of Japanese Society of Systematic Zoology, 20: 26-40 [in Japanese with English abstract].

Ozawa, H. 2007. Faunal changes of cryophilic ostracods (Crustacea) in the Japan Sea, in relation to oceanographic environment: an overview. Fossils (Palaeontological Society of Japan), 82: 22-30 [in Japanese with English abstract].

Ozawa, H. \& Kamiya, T. 2001. Palaeoceanographic records related to glacio-eustatic sea-level fluctuations in the Pleistocene Japan Sea coast based on ostracods from the Omma Formation. Palaeogeography, Palaeoclimatology, Palaeoecology, 170: 27-48.

Ozawa, H. \& Kamiya, T. 2005a. The effects of glacio-eustatic sea-level change on Pleistocene cold-water ostracod assemblages from the Japan Sea. Marine Micropaleontology, 54: 167-189.

Ozawa, H. \& Kamiya, T. 2005b. Ecological analysis of benthic ostracods in the northern Japan Sea, based on water properties of modern habitats and late Cenozoic fossil records. Marine Micropaleontology, 55: 255-276.

Ozawa, H., Kamiya, T. \& Tsukagoshi, A. 1995. Ostracode evidence for the paleoceanographic change of the middle Pleistocene Jizodo and Yabu Formations in the Boso Peninsula, central Japan. Science Report of Kanazawa University, 40: 9-37. 
Ozawa, H., Ikehara, K. \& Katayama, H. 1999. Recent ostracode fauna in the northeastern part of the Japan Sea, off northwestern Hokkaido. In: Ikehara, K. \& Okamura, Y. (Eds), Comprehensive study on environmental changes in the western Hokkaido coastal area and study on evaluation of marine active faults. Geological Survey of Japan, Tsukuba, 103-117 [in Japanese, title translated].

Ozawa, H., Kamiya, T., Itoh, H. \& Tsukawaki, S. 2004a. Water temperature, salinity ranges and ecological significance of the three families of Recent cold-water ostracods in and around the Japan Sea. Paleontological Research, 8: 11-28.

Ozawa, H., Kamiya, T., Kato, M. \& Tsukawaki, S. 2004b. A preliminary report on the Recent ostracodes in sediment samples from the R.V. Tansei-maru Cruise KT01-14 in the southwestern Okhotsk Sea and the northeastern Japan Sea off Hokkaido. Bulletin of Japan Sea Research Institute, 35: 33-46.

Raymo, M., Ruddiman, W., Backman, J., Clement, B. \& Martinson, D. 1989. Late Pliocene variation in northern hemisphere ice sheets and North Atlantic Deep Water Circulation. Paleoceanography, 4: 413-446.

Sato, T., Higuchi, T., Ishii, T., Yuguchi, S., Amano, K. \& Kameo, K. 2003. Calcareous nannofossil biostratigraphy of the upper Pliocene to lowermost Pleistocene distributed in the northern part of Akita Prefecture, Honshu, Japan - with special reference to the late Pliocene paleoceanography event. Journal of Geological Society of Japan, 109: 280-292 [in Japanese with English abstract].

Sato, T., Yuguchi, S., Takayama, T. \& Kameo, K. 2004. Drastic change in the geographical distribution of the cold-water nannofossil Cocolithus pelagicus (Wallich) Schiller at $2.74 \mathrm{Ma}$ in the late Pliocene, with special reference to glaciation in the Arctic Ocean. Marine Micropaleontology, 52: 181-193.

Tabuki, R. 1986. Plio-Pleistocene Ostracoda from the Tsugaru Basin, North Honshu, Japan. Bulletin of College of Education, University of Ryukyus, 29: 27-160.

Tabuki, R. 2001. Plio-Pleistocene and Recent subtropical Ostracoda in Okinawa. In: Ikeya, N. (Ed.), Field Excursion Guidebook; 14th International Symposium of Ostracoda, Shizuoka. Organising Committee of 14th ISO, Shizuoka, 21-44.

Tada, R. 1994. Paleoceanographic evolution of the Japan Sea. Palaeogeography, Palaeoclimatology, Palaeoecology, 108: 487-508.

Tanaka, G. 2003. Middle Miocene ostracods from the Omori Formation, Izumo City, Southwest Japan - Its implications for paleoenvironment of the Proto-Japan Sea. Earth Science (Chikyu-Kagaku), 57: 111-127.

Tanaka, G. \& Ikeya, N. 2002. Migration and speciation of the Loxoconcha japonica species group (Ostracoda) in East Asia. Paleontological Research, 6: 265-284.

Tanaka, G., Seto, K., Mukuda, T. \& Nakano, Y. 2002. Middle Miocene ostracods from the Fujina Formation, Southwest Japan and their paleoenvironmental significance. Paleontological Research, 6: 1-22.

Tanaka, G., Tsukawaki, S. \& Ooji, A. 2004. Preliminary report on Ostracodes from the Miocene Sunagozaka Formation, southern part of Kanazawa City, Ishikawa Prefecture, central Japan. Bulletin of Japan Sea Research Institute, 35: 53-63 [in Japanese with English abstract].
Thomas, E. \& Gooday, A.J. 1996. Cenozoic deep-sea benthic foraminifers: Tracers for changes in oceanic productivity? Geology, 24: 355-358.

Tsuchi, R. \& Ibaraki, M. 1988. Note on the Omma-Manganji molluscan fauna: Its geological age and paleoceanographic implications. Saito Ho-on Kai Special Publication, no. 2 (Professor T. Kotaka Commemorative Volume: 557-565.

Tsukawaki, S., Kamiya, T., Kato, M., et al. 1997. Preliminary results from the R.V. Tansei-maru Cruise KT95-14 Leg 2 in the southern marginal area in the Japan Sea - Part 1: sediments, benthic foraminifers and ostracodes. Bulletin of Japan Sea Research Institute, 28: $13-43$.

Tsukawaki, S., Kamiya, T., Ozawa, H. \& Kato, M. 1998. Preliminary results on the sediment samplings from the R.V. Tansei-maru Cruise KT96-17 Leg 2 in the southwestern part of the Japan Sea - sediments, benthic foraminifers and ostracodes. Bulletin of Japan Sea Research Institute, 29: 67-89.

Tsukawaki, S., Ozawa, H., Domitsu, H., Tanaka, Y., Kamiya, T., Kato, M. \& Oda, M. 1999. Preliminary results from the R.V. Tansei-maru Cruise KT97-15 in the eastern marginal part of the Japan Sea off Tsugaru Peninsula, Northeast Japan - sediments, benthic and planktonic foraminifers and ostracodes. Bulletin of Japan Sea Research Institute, 30: 99-140.

Tsukawaki, S., Ozawa, H., Domitsu, H., Kamiya, T., Kato, M. \& Oda, M. 2000. Preliminary results from the R.V. Tansei-maru Cruise KT98-17 in the southwestern marginal part of the Japan Sea sediments, benthic and planktonic foraminifers, and ostracodes. Bulletin of Japan Sea Research Institute, 31: 89-119.

Tsukawaki, S., Ozawa, H., Domitsu, H., et al. 2001. Preliminary results from the R.V. Tansei-maru Cruise KT99-14 in the central and northeastern marginal part of the Japan Sea - sediments, benthic and planktonic foraminifers, and ostracodes (Part 1: surface sediments). Bulletin of Japan Sea Research Institute, 32: 1-28.

Whatley, R., Ballent, S. \& Szczechura, J. 2005. Antarctic Tertiary Progonocytheridae: The last refuge of Majungaella, the survivor of a long lineage, a geographical and physiological migration from low to high latitudes. Palaeogeography, Palaeoclimatology, Palaeoecology, 225: $27-48$.

Yamada, K., Irizuki, T. \& Tanaka, Y. 2002. Cyclic sea-level changes based on fossil ostracode faunas from the upper Pliocene Sasaoka Formation, Akita Prefecture, central Japan. Palaeogeography, Palaeoclimatology, Palaeoecology, 185: 115-132.

Yamada, K., Irizuki, T. \& Tanaka, Y. 2005. Paleoceanographic shifts and global events recorded in late Pliocene shallow marine deposits (2.80-2.55 Ma) of the Sea of Japan. Palaeogeography, Palaeoclimatology, Palaeoecology, 220: 255-271.

Yanagisawa, Y. 1999. Diatom biostratigraphy of the Miocene sequence in the southern Kanazawa area, Ishikawa Prefecture, central Japan. Bulletin of Geological Survey of Japan, 50: 49-65 [in Japanese with English abstract].

Zhou, B.C. 1995. Recent ostracode fauna in the Pacific off Southwest Japan. Memoirs of Faculty of Science, Kyoto University, Series of Geology \& Mineralogy, 57: 21-98. 